\title{
PNL-2670
}

UC-35

\section{Radiological and Toxicological Assessment of an External Heat (Burn) Test of the 105MM Cartridge, APFSDS-T, XM-744}

by

R. L. Gilchrist, Project Manager

G. B. Parker

J. Mishima

March 1978

Pacific Northwest Laboratory

Richland, Washington 99352

Operated for the

U.S. Department of Energy

by 
This report was prepared as an account of work sponsored by the United States Government. Neither the United States nor the Department of Energy, nor any of their employees, nor any of their contractors. subcontractors, or their empioyees, makes any warranty, express or implied, or assumes any legal liability or responsibility for the accuracy, completeness or usefuiness of any information, apparatus, product or process disclosed, or represents that its use wouid not infringe privately owned rights.

The views, opinions and conclusions contained in this report are those of the contractor and do not necessarily represent those of the United States Government or the United States Department of Energy

\author{
PACIFIC NORTHWEST LABORATORY \\ operated by \\ BATTELLE \\ for the \\ UNITED STATES DEPARTMENT OF EINERGY \\ Under Contract $E Y-76-C-06-1830$
}

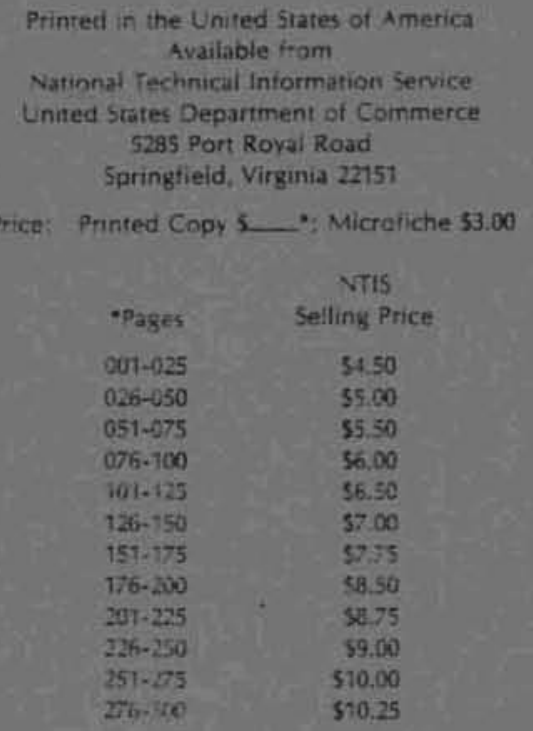




\title{
33679000493199
}

RADIOLOGICAL AND TOXICOLOGICAL ASSESSMENT OF AN EXTERNAL HEAT (BURN) TEST OF THE $105 \mathrm{~mm}$ CARTRIDGE, APFSDS-T, XM-

$$
794
$$

\footnotetext{
by
}

R.L. Gilchrist, Project Manager G.B. Parker

J. Mishima

March 1978

\author{
Battelle \\ Pacific Northwest Laboratories \\ Richland, Washington 99352
}




\section{NOT ICE}

The views, opinions, and/or findings contained in this report are those of the author(s) and should not be construed as an official Department of the Army position, policy, or decision, unless so designated by other documentation. 
August 23,1978

TO RECIPIENTS OF PNL 2670:

Subject: Errata list for PNL 2670, Radiological and Toxicological Assessment of an External Heat (Burn) Test of the $105 \mathrm{~mm}$ Cartridge, APFSDS-T, XM-744

The following errors were brought to my attention. Please make these corrections on the cover and on the title page of the document. I apologize for any inconvenience or misunderstanding these errors may have caused.

Cover page: Change the title from ". . . 105 MM Cartridge, APFSDS-T, XM-744" to ". . . $105 \mathrm{~mm}$ Cartridge, APFSDS-T, $X M-\underline{774} . "$

Title page: Change the title from ". . APFSOS-T, XM-744" to ". . . APFSDS-T, XM- $774 . "$

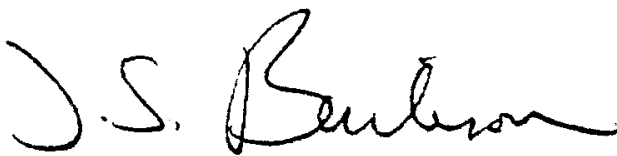

J. S. Burlison

Editor/Writer

(509) $946-3796$ 

Pacific Northwest Laboratory conducted research to assess the potential radiological and toxicological hazard of depleted uranium aerosol release. This type of release might arise from accidents with XM-774 ammunition involving great heat.

Twe ive rounds of packaged ammunition were subjected to an external heat (burn) test. Examination of the site on the day following the test revealed that a 1112 depleted uranium penetrators were completely intact. Oxidation of the penetrators was not apparent, even on the most severely burned projectile located at ground zero. Eleven of the 12 projectiles were recovered with the sabots intact; some sabots appeared charred.

It was concluded that no airborne release of depleted uranium had occurred and subsequently there had been no radiological or toxicological hazard from DU during this test. However, this conclusion may not apply to the release of depleted uranium in other types of fires involving this ammunition because other factors may affect the fire. These factors include type of fuel, number of ammunition rounds, and type of structure housing the ammunition. 


\section{CONTENTS}

SUMMARY .

FOREWORD . . . . . . . . . . . . . . . . . . . . . . . . . . .

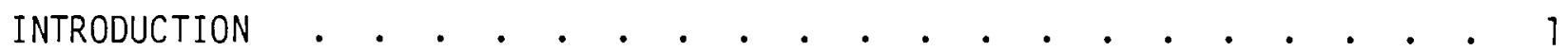

OBJECTIVE • • • • • • • • • • • • • • • •

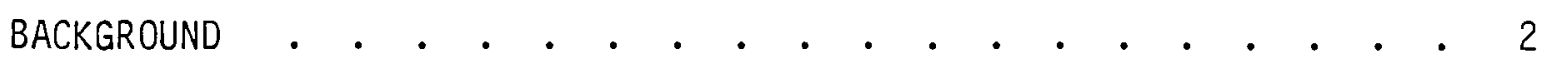

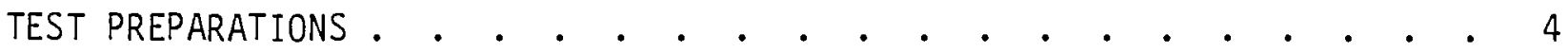

TEST DESCRIPTION

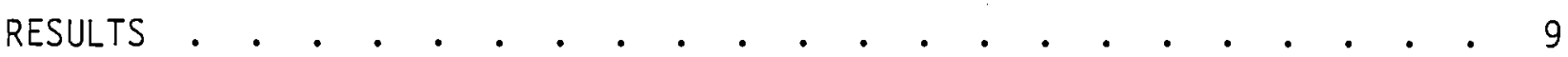

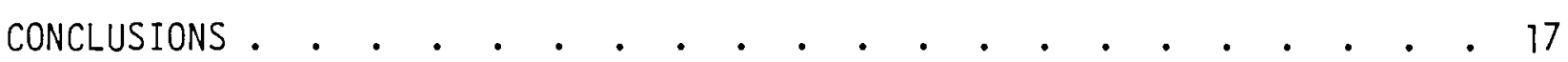

APPENDIX - OXIDATION AND IGNITION OF DEPLETED URANIUM . • • • • • • 21

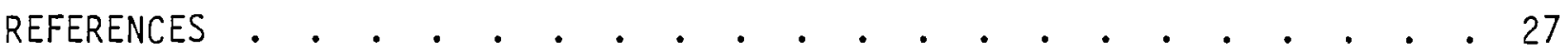




\section{FIGURES}

FIGURE 1. Aerial Photograph of Burn Test Site. . . . . . . . 5

FIGURE 2. Aerial Photograph of First $100 \mathrm{ft}$ of Grid for the Burn Test . . . . . . . . . . . 6

FIGURE 3. Ammunition and Wood Prior to Burning--Fuel Being Added . 7

FIGURE 4. Fire and Explosion During Burn . . . . . . . . . 8

FIGURE 5. Schematic of Test Grid Indicating Position and Distances from Ground Zero of Projectiles After Burn Test . 9

FIGURE 6. Aerial Photograph of Burn Site Noting the Location of Each Penetrator After Burn Test . . . . . 10

FIGURE 7. Composite Photograph of the Twelve Penetrators as Discovered After Burn Test. . . . . . . . . . 12, 13

FIGURE 8. Comparison of Three Projectiles Subjected to the Burn Test. . . . . . . . . . 16

FIGURE A-1. Effect of Temperature on Heat Loss or Heat Generation Rates . . . . . . . . . 23

FIGURE A-2. Dependence of Uranium Ignition on Specific Area . . . 23

FIGURE A-3. Percentage of $\mathrm{U}_{3} \mathrm{O}_{8}$ Formed by Oxidizing Uranium in Air . . . . . . . . . . 25

FIGURE A-4. Size Distribution of $\mathrm{U}_{3} \mathrm{O}_{8}$ Powder by Air Oxidation of a Sintered $\mathrm{UO}_{2}$ Pellet at $5000^{\circ} \mathrm{C}$ for One Hour. . . . . 25 


\section{FOREWORD}

This study was conducted on the recommendation of the Joint Technical Coordinating Group/Munitions Effectiveness (JTCG/ME) Working Group on Depleted Uranium and was supported by the Office of Assistant Project Manager for Tank Main Armament Development, XMI Tank System, under Army Project No. IL663608D060. The technical monitors were the Working Group Chairman, Ernest W. BToore, and Edward F. Wilsey, both of the U.S. Army Armament Research and Development Command's (ARADCOM) Ballistic Research Laboratory (BRL). The study supplemented the Hazard Classification Test ${ }^{(1)}$ conducted by Gary J. Gray of ARADCOM's Large Caliber Weapon Systems Laboratory (LCWSL). The success of the test and this study was attributable to the coordination and support efforts of the U.S. Department of Energy (DOE) Nevada Operation Office, Office of Special Projects; the DOE Nevada Test Site and Contractor personnel, especially Linden Kelly, Site Manager; and the Nellis Air Force Base Explosive Ordinance Disposal (EOD) team, headed by Sgt. Jesse Campbe11. 


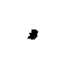




\section{INTRODUCTION}

This report describes work done by Pacific Northwest Laboratory $(P N L)^{(a)}$ for the Joint Technical Coordinating Group/Munitions Effectiveness (JTCG/ME) Working Group on DU to supplement the burn test and was conducted simultaneously with the fragment pattern test, to assess the potential for airborne release of depleted uranium (DU) aerosol, and the subsequent radiological and toxicological hazard from XM-774 ammunition exposed to accidents involving extreme heat. Each round of this ammunition contains a penetrator core of $3.3 \mathrm{~kg}$ of depleted uranium, which is classified as a radioactive source material and a toxic heavy metal. In this hazard classification test, 12 boxed rounds of ammunition, packaged in conventional shipping/storage containers, were burned in a wood bonfire at Frenchman Flat (within the DOE/Nevada Test Site) on October 17-20, 1977.

\section{OBJECTIVE}

The objective of this effort was to assess the radiological and toxicological significance of the potential airborne release of depleted uranium aerosol from XM-774 ammunition during an external heat (burn) test. Each round of this ammunition contains a uranium based alloy penetrator whose composition is uranium- $0.75 \mathrm{w} / \mathrm{O}$ titanium.

The procedures for establishing and conducting an external heat test are described in TB-700-2. (2) The test is one of a series designed to determine the appropriate hazard classification of ammunition storage and handling. The objective of the standard burn test is to determine the pattern of fragments resulting from the ammunition "cooking-off" during the fire and within a 500-ft radius of the fire. This standard test is not designed to assess the release of $D U$ to the atmosphere.

\section{BACKGROUND}

There was no previous experience in the burning or fragmentation of XM-774 ammunition. Preparations were made assuming that the DU penetrators

(a) PNL is operated by Battelle Memorial Institute. 
would fragment and burn, and that an aerosol would be released during the test. Work was done before the test to determine procedures to account for the uranium found on the ground and, by mass differences, to estimate the airborne release of DU. These procedures are explained more fully in the section on Test Preparations.

The conventional method of measuring the release of a substance to the atmosphere normally would require an extensive air sampling network consisting of several towers and several hundred samplers in a predetermined downwind array, from which measurements would be taken during several release periods. However, because the radiological and toxicological assessment was not to interfere with the standard burn test, the time available for preparation was limited, and only one bonfire was to be conducted, an alternative approach was formulated. This approach required careful collection of all readily visible depleted uranium fragments after the test and a determination, by mass balance, of the amount of DU released as an derosol.

It was anticipated that the majority of the DU fragments could be visually identified and recovered. The difference between the total weight of the twelve penetrators and the total weight of the fragments would give the mass of DU unaccounted for, and this difference would be assumed to be the maximum airborne release of DU from the test. If the mass difference unaccounted for was greater than approximately $30 \%$ of the original mass of DU, an additional search for DU would be conducted. This second search would be performed using either a standard Geiger-Mueller (GM) (a) counter or Field Instrument for Detection of Low Energy Radiation (FIDLER) ${ }^{(b)}$ to locate DU fragments. Three two-man teams composed of engineers from PNL and personnel from Reynolds Electrical and Engineering Company, Inc. (REECO) at the Nevada Test Site would conduct this second DU recovery operation.

To prepare for this part of the task, PNL personnel spent time in the field evaluating techniques for using these instruments to detect small

(a) Eberline E-140 Count Meter with Microwindow GM Probe.

(b) Eberline SAM-2 with RO-21 Stabilized Scintilation Detector. 
amounts of DU. It was demonstrated that the GM counter was the best instrument for detecting DU quantities as small as $1 \mathrm{~g}$ (about 1/4 in. in diameter) from about $2 \mathrm{in}$. above the sample. The FIDLER was found to be more sensitive for small samples $(<10 \mathrm{~g})$ which were slightly buried in the sand. Both instruments could detect an unburied $1 \mathrm{~g}$ sample of DU; however, the GM was found to be more convenient to use due to its lighter weight.

The accuracy of this method to estimate aerosol release was determined to be no better than $20 \%$ to $30 \%$, unless most of the projectiles could be recovered intact. Onty one test was scheduled and this test was to include 12 rounds of ammunition. Data from this test were also to be used to estimate release of airborne DU from much larger quantities of ammunition.

After computing the fraction of DU unaccounted for, which was assumed to be airborne, the airborne concentration downwind and integrated dose to an individual at a selected distance downwind would be calculated. From a radiological standpoint, it is known that a relatively large amount of depleted uranium can become airborne without exceeding the maximum allowable exposure to humans some distance downwind. From a chemical toxicity standpoint, the maximum allowable release of DU that will not exceed the threshold limit value (TLV) is calculated according to correlations available for chemical sources released to the atmosphere. 


\section{TEST PREPARATIONS}

An area within the Nevada Test Site was chosen for the burn test based upon the following criteria: 1) the site was relatively free of vegetation and debris within a radius of $500 \mathrm{ft}$ from the burn center, 2) the area was flat, 3) the radiation background level in the area was low and uniform, and 4) there was a shelter nearby for weighing the test specimens and observing the test. The site chosen, Frenchman Flat, is a dry lake bed about 10 miles north of Mercury, Nevada (Figure 1).

A grid pattern was plotted with white chalk link to locate fragments thrown out by the exploding mounds in the fire. This pattern had radial lines 30 degrees apart which extended $500 \mathrm{ft}$ from the center of the pattern. Each radial line was marked with chalk at $20-\mathrm{ft}$ intervals from the center to $100 \mathrm{ft}$ and at $100-\mathrm{ft}$ intervals from $100 \mathrm{ft}$ to $500 \mathrm{ft}$. Circumferential lines were plotted connecting al1 radial distance marks out to $200 \mathrm{ft}$. The radial distances and angles were marked with black spray paint. The close-in portion of the pattern is shown in Figure 2.

REECO personne 1 performed a radiation survey of the burn area to assess background readings in the area. The background readings were measured with both a GM counter and a FIDLER. Background reading on the FIDLER was low and uniform, between 300 to 400 counts/min. It was determined that interference from the background would not be a problem if it became necessary to survey the area to locate DU fragments. A single high volume air sampler was set at the $100-\mathrm{ft}$ mark at $270^{\circ}$, the anticipated downwind direction, to collect a sample for use by the radiological safety personnel at the test site. A trailer located near the burn site was to be used for the field weighing work. 


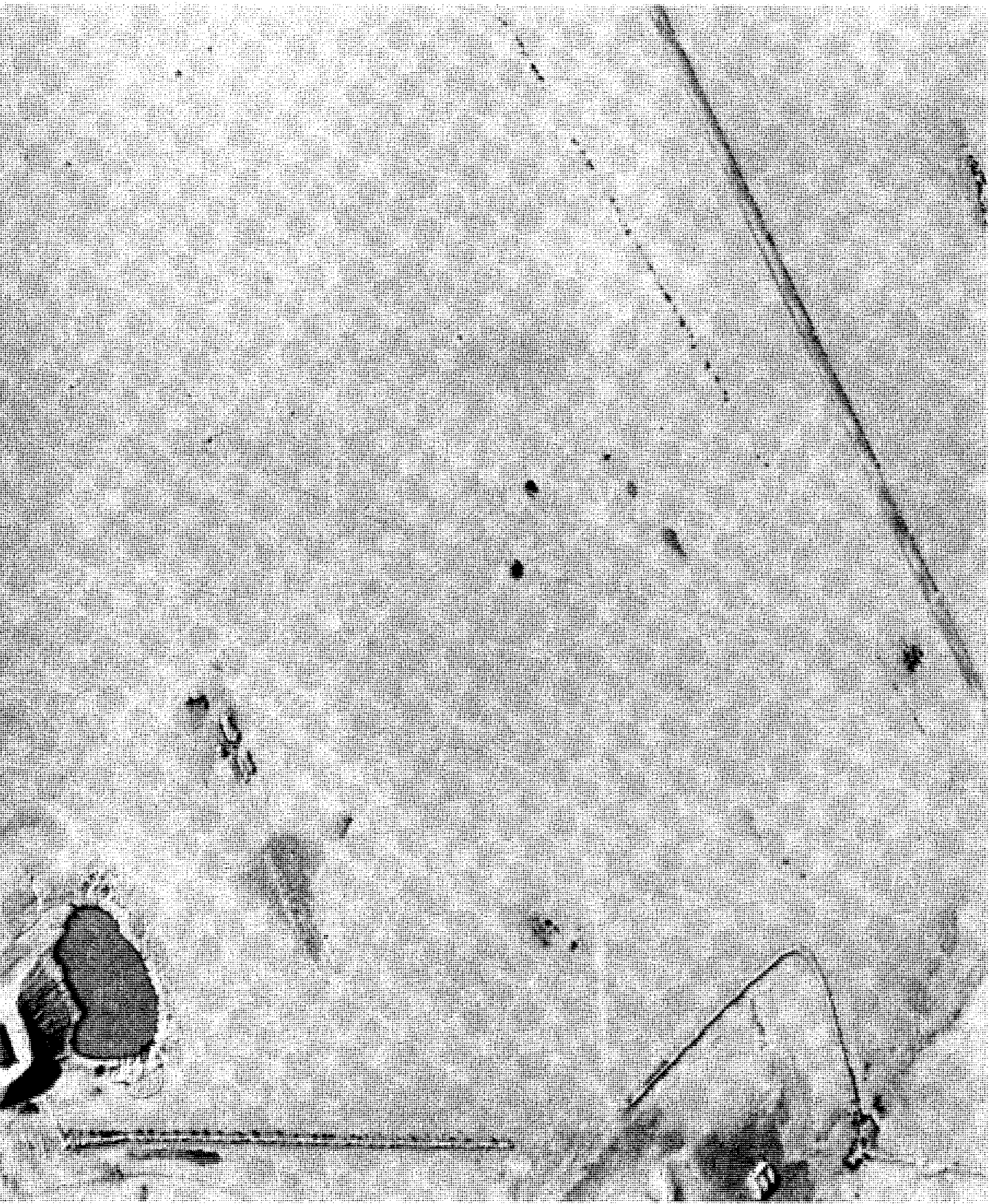

FIGURE 1. Aerial Photograph of Burn Test Site 


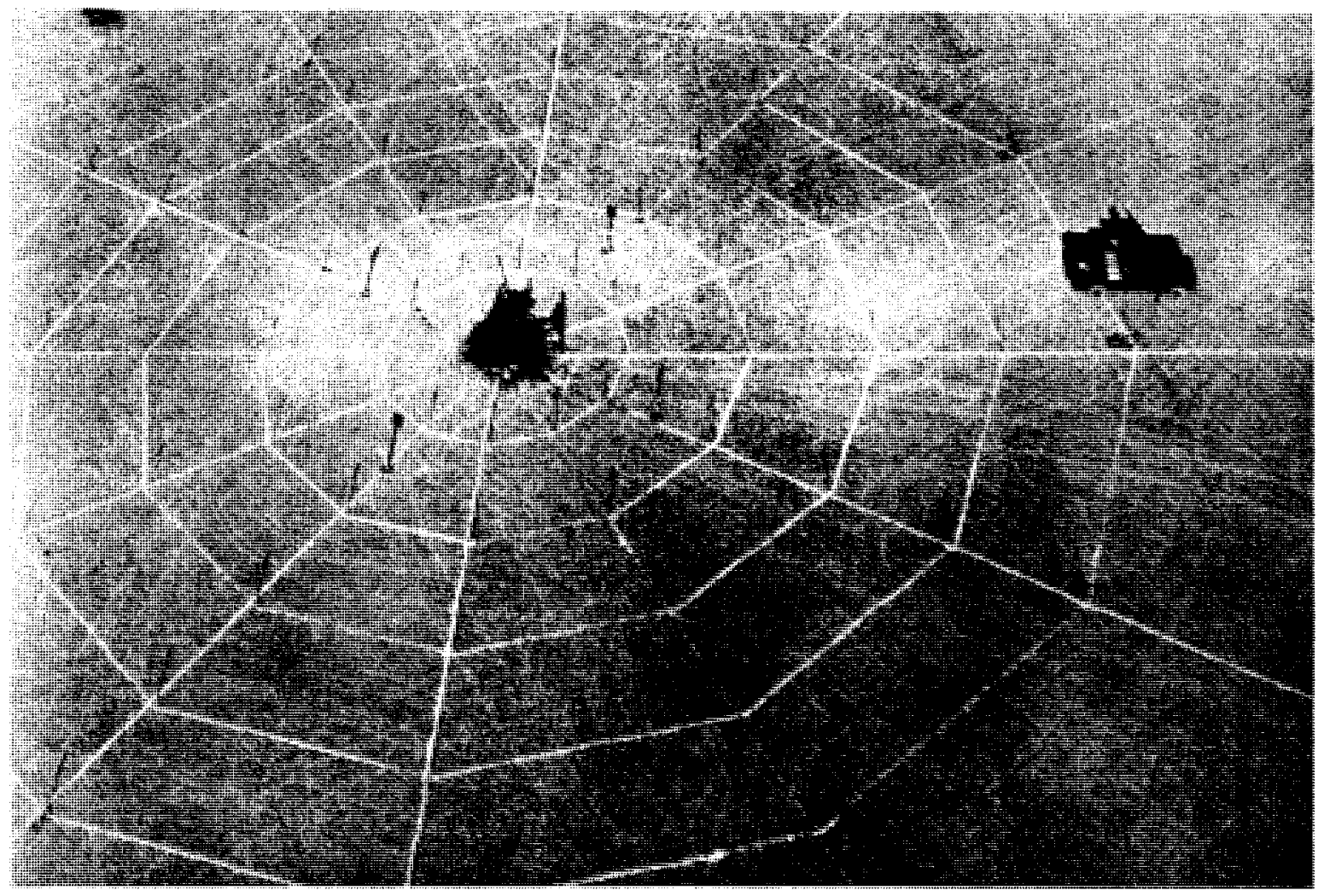

FIGURE 2. Aerial Photograph of First $100 \mathrm{ft}$ of Grid for the Burn Test 
Twelve rounds of ammunition were stacked and strapped to an open metal "table" at the center of the grid. Each round was encased in a cylindrical, impregnated, fiber-reinforced cardboard container with plastic packaging inserts and metal cap ends. Two containers with the rounds positioned in opposite directions were placed in a standard shipping container for $105 \mathrm{~mm}$ ammunition, a rectangular wooden box with a hinged lid. The six boxes were oriented east-west along the $90^{\circ}-270^{\circ}$ lines of the grid. Wood was stacked under, around, and on top of the boxes and soaked with 50 gallons of diesel fuel. Figure 3 shows the boxes and the wood before the fire was ignited. An Air Force Explosive Ordinance Demolition (EOD) team set a time detonator fuse in the pile to initiate burning. The actual burn started at 1615 hours on October 18, 1977.

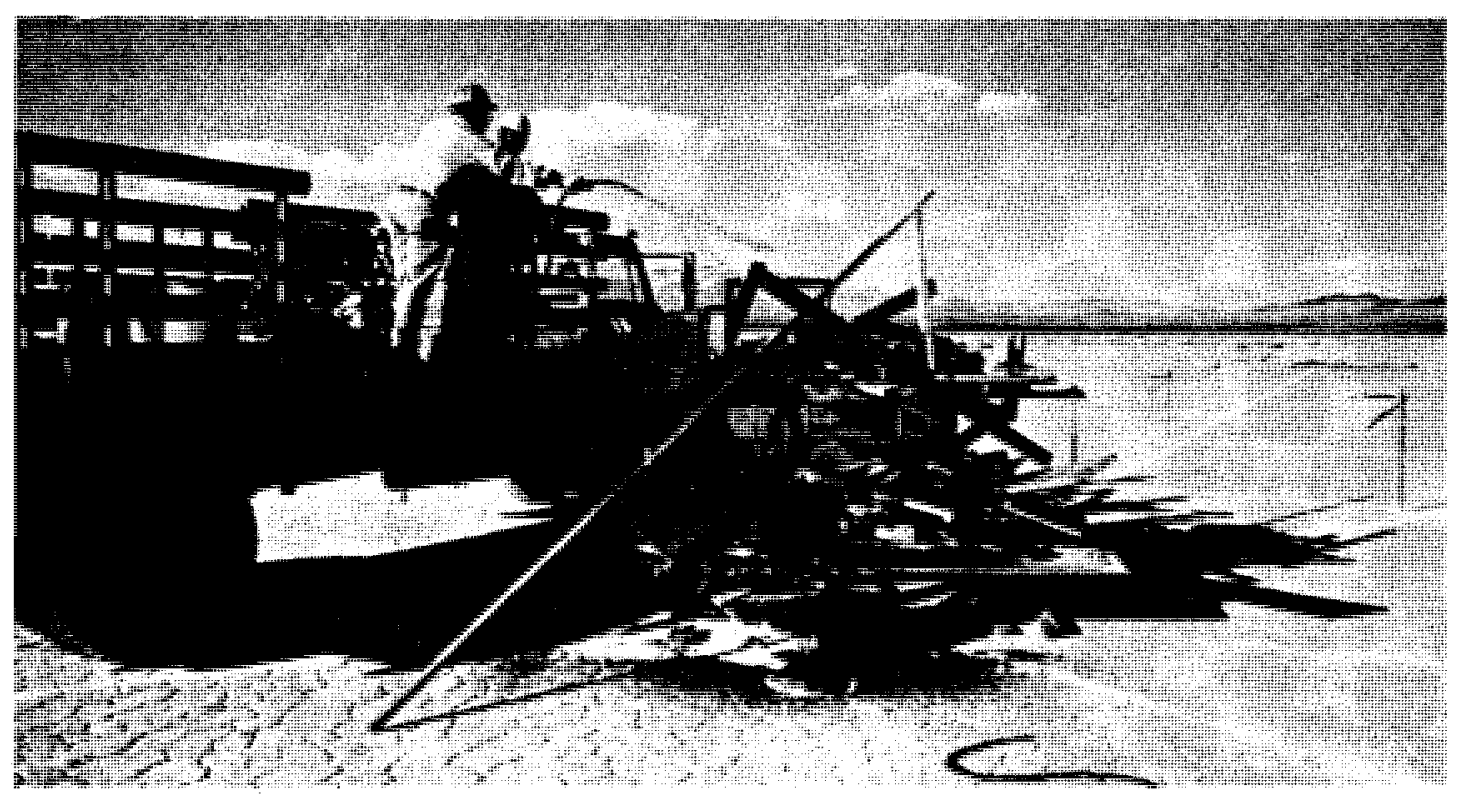

FIGURE 3. Ammunition and Wood Prior to Burning--Fuel Being Added 
The fuel and wood burned for approximately 17 minutes before the first round exploded. In 10 minutes, from about 1632 to 1642 hours, nine more explosions occurred. Burning of pink-orange tracers was noted on several occasions. Figure 4 shows the fire and one of the explosions. The fire extinguished itself shortly after the last explosion. No one was allowed to enter the area until the next day. During the fire, complete photographic coverage was provided by two video tape units at $500 \mathrm{ft}$ and $1000 \mathrm{ft}$, a movie camera at $1000 \mathrm{ft}$, still pictures at $1000 \mathrm{ft}$, and still aerial photography from a helicopter.

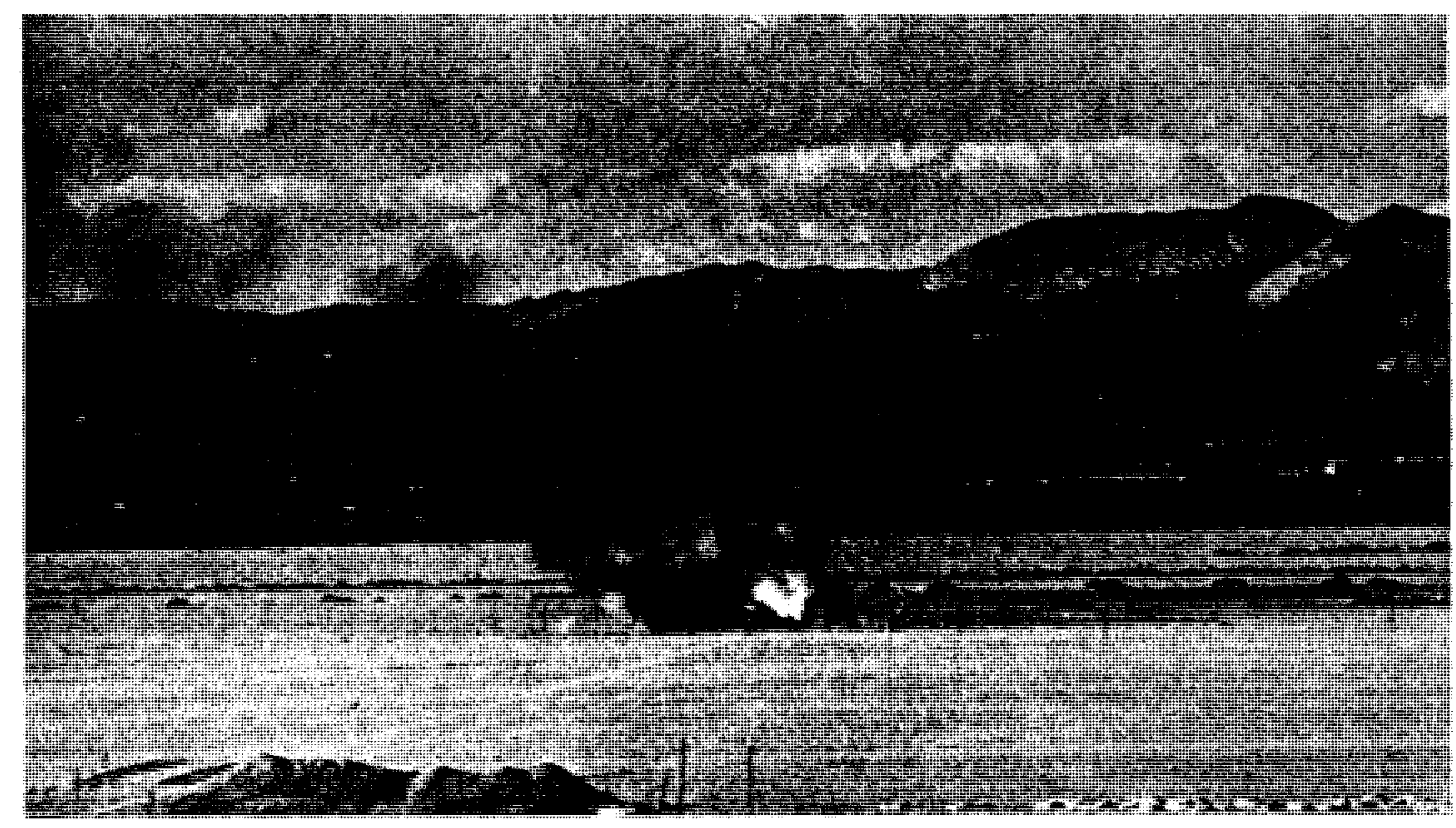

FIGURE 4. Fire and Explosion During Burn Test 


\section{RESULTS}

The test site was entered and inspected on the morning of October 19, 1977 by the Air Force EOD team and was declared safe to enter. The area was littered with debris of all kinds, including shell casings, container sections, and a large number of propellent pellets. All 12 projectiles with their DU penetrators were located within the 500-ft grid and were completely intact. No penetrator had fragmented during the test.

Locations of the projectiles were identified first by painting a circle around them with fluorescent orange paint, and then by noting their exact location on the grid. Each projectile was then photographed. Figure 5 is a schematic of the grid with the location of each projectile noted by the radial distance in feet from ground zero and labeled with a letter designation. Figure 6 is an aerial photograph of the burn site showing the 12 projectiles circled with orange paint and labeled with letters corresponding to Figure 5 .

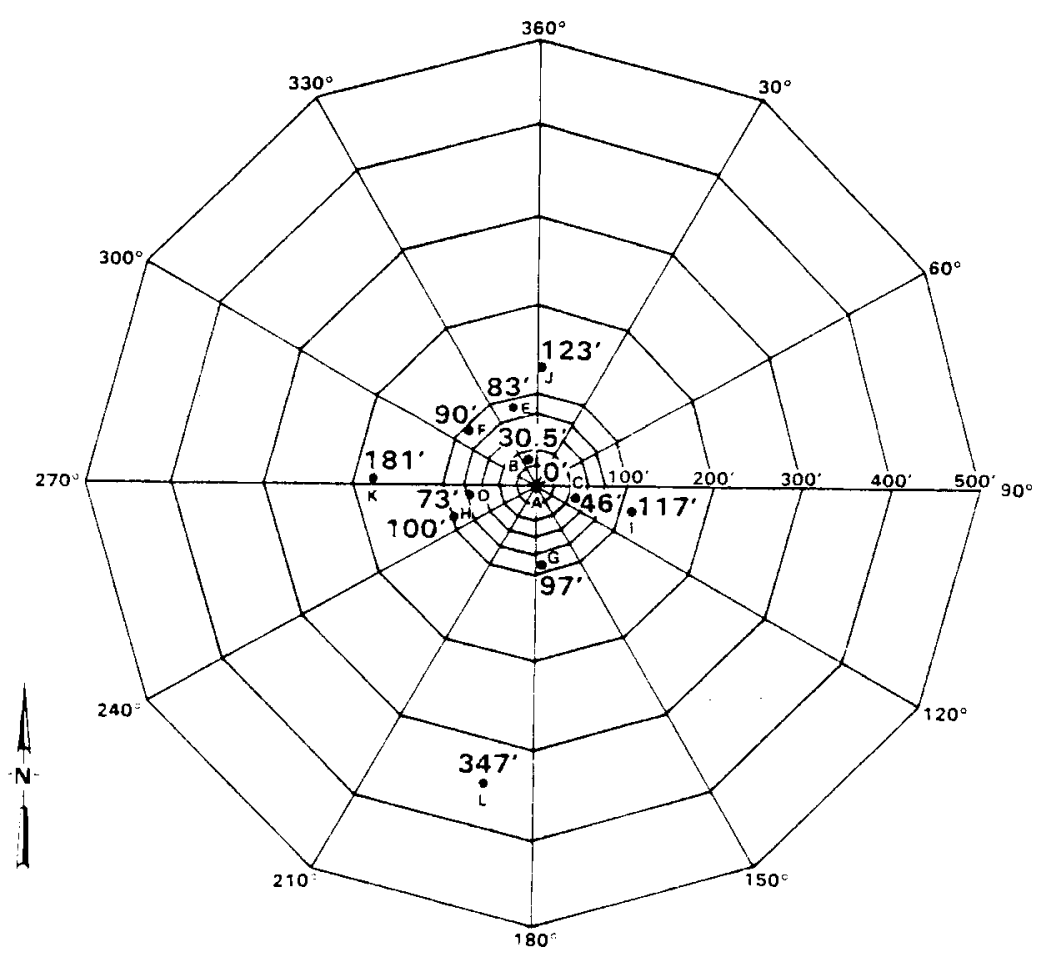

FIGURE 5. Schematic of Test Grid Indicating Position and Distances from Ground Zero of Projectiles After Burn Test 


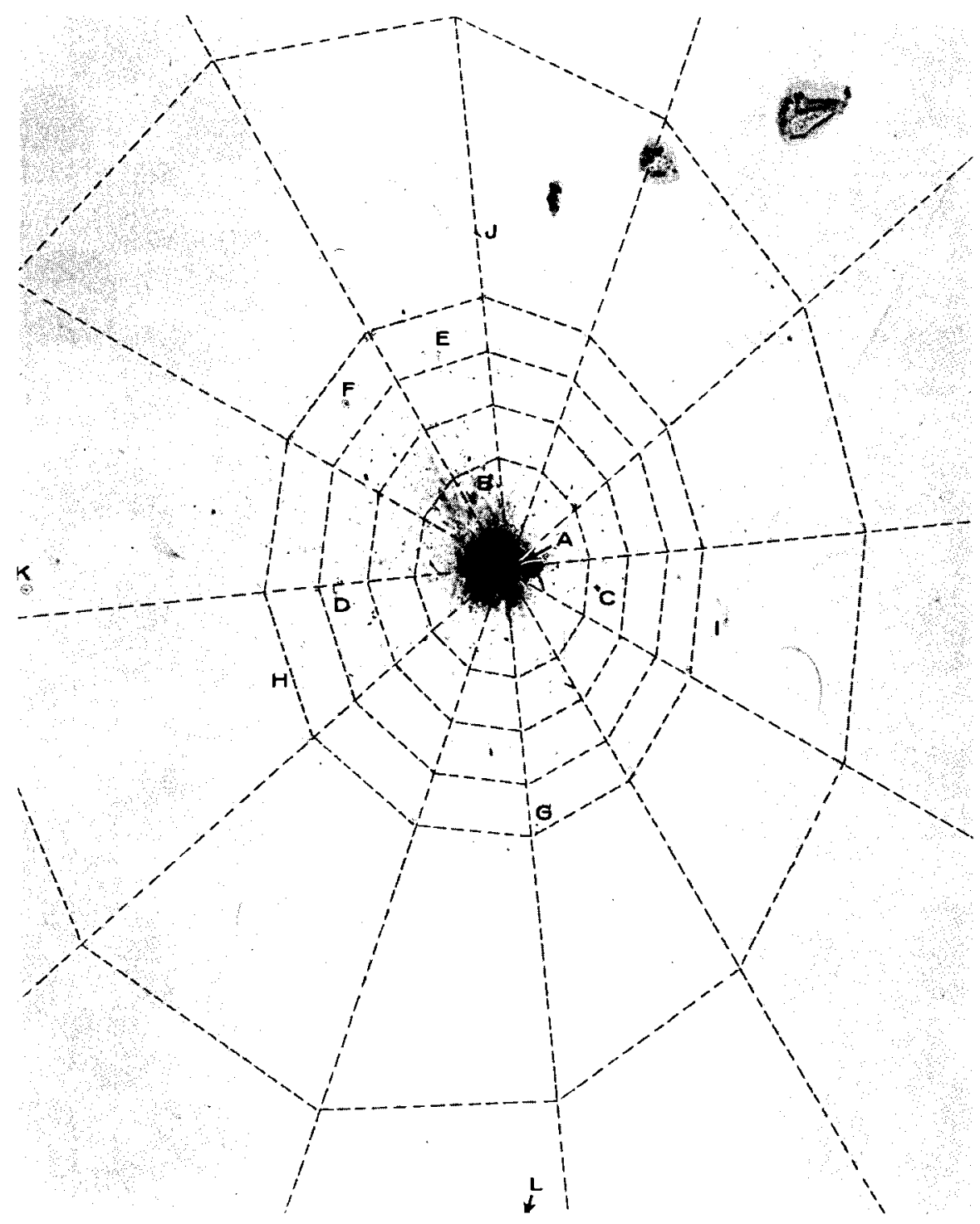

FIGURE 6. Aerial Photograph of Burn Site Noting the Location of Each Projectile

Figure 7 is a composite of the 12 projectiles as they were found at the burn site. They are given letter designations according to the radial distance at which they were found from the center of the test (ground zero); projectile $A$ is the closest $(0 \mathrm{ft})$ and projectile $L$ the farthest away $(347 \mathrm{ft})$. As shown in Figure 6 , no two projectiles were found at exactly the same distance from ground zero. A brief physical description of each follows. 


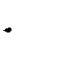

.

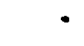



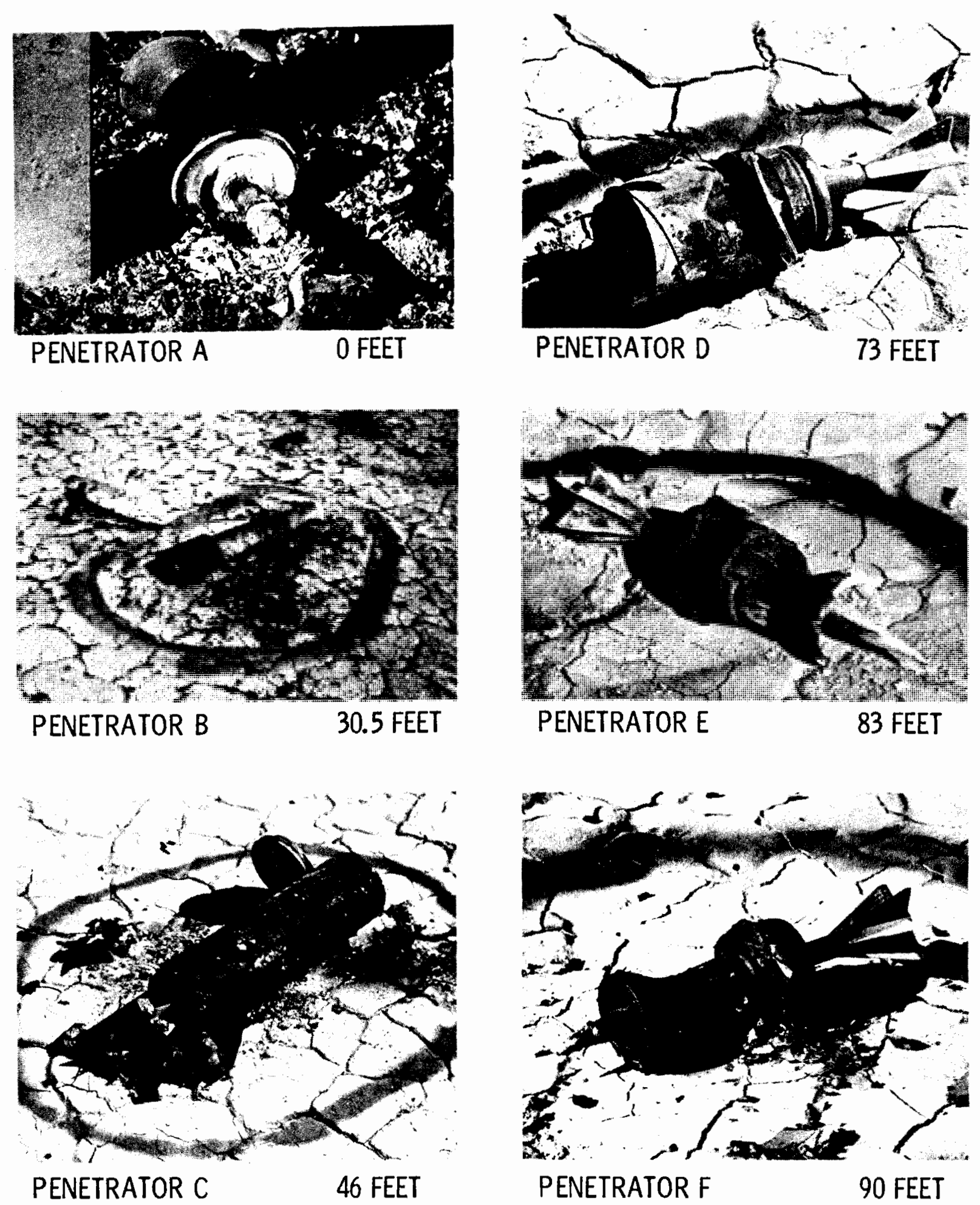

FIGURE 7. Composite Photograph of the Twelve Penetrators as Discovered After Burn Test 

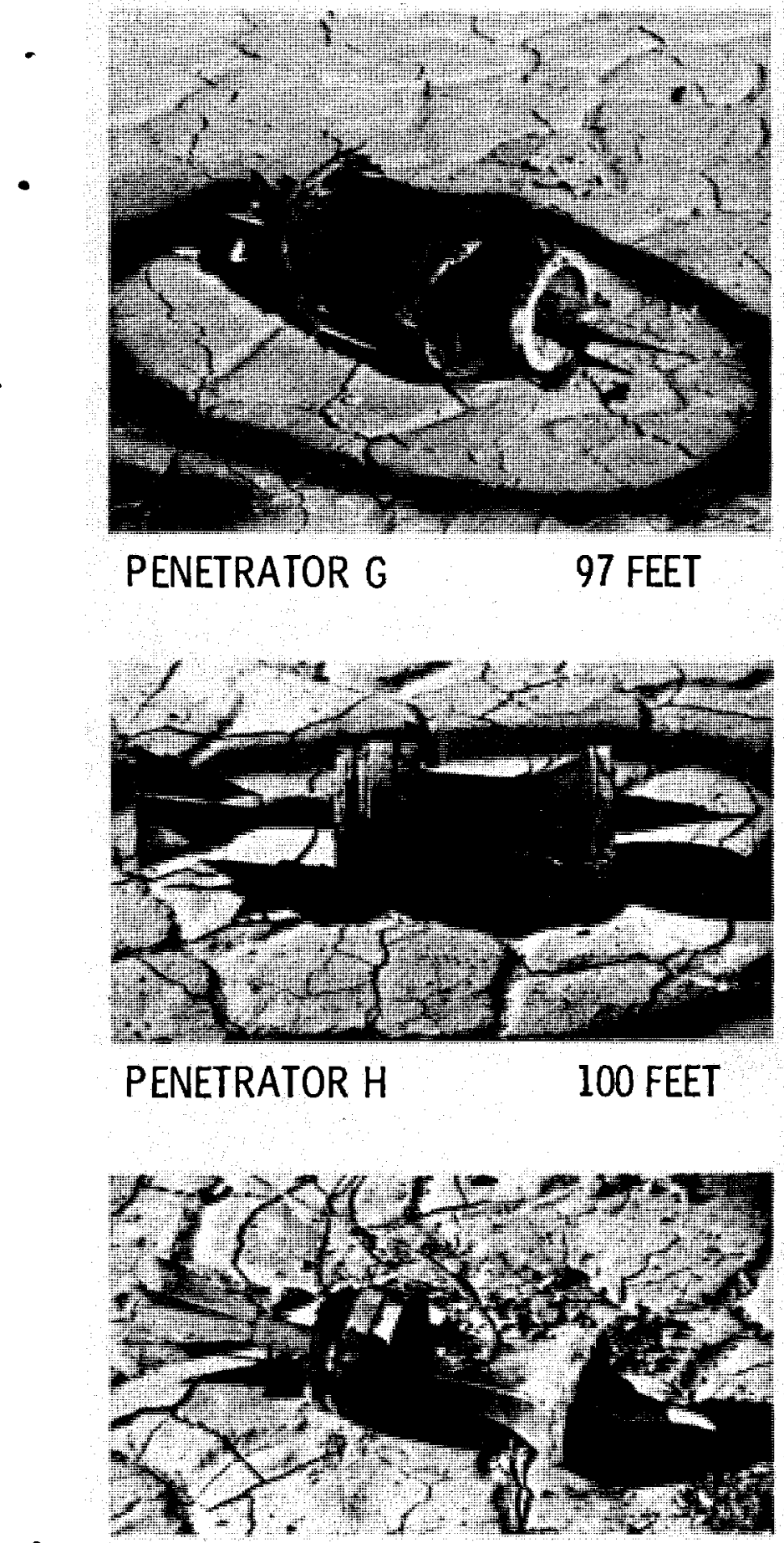

PENETRATOR I

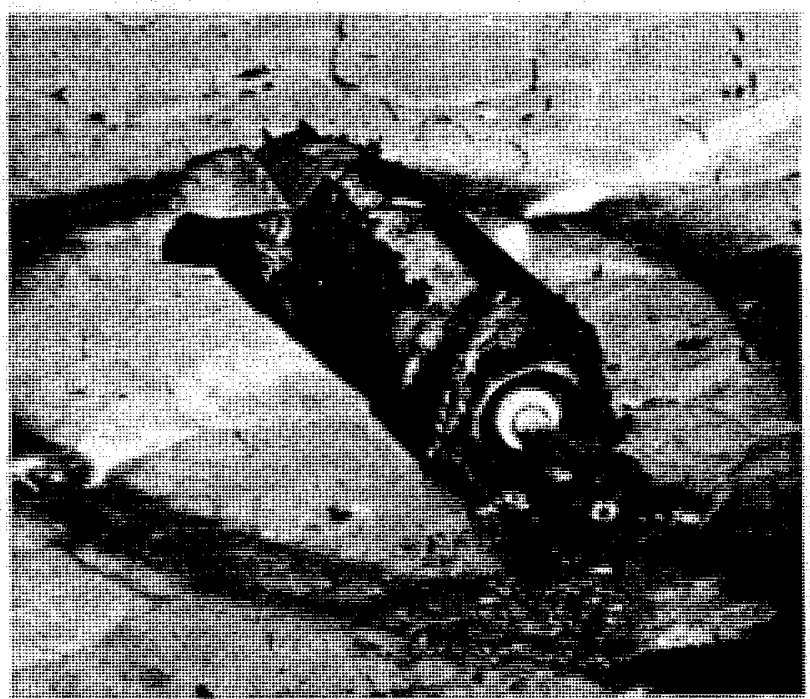

PENETRATOR J

123 FEET
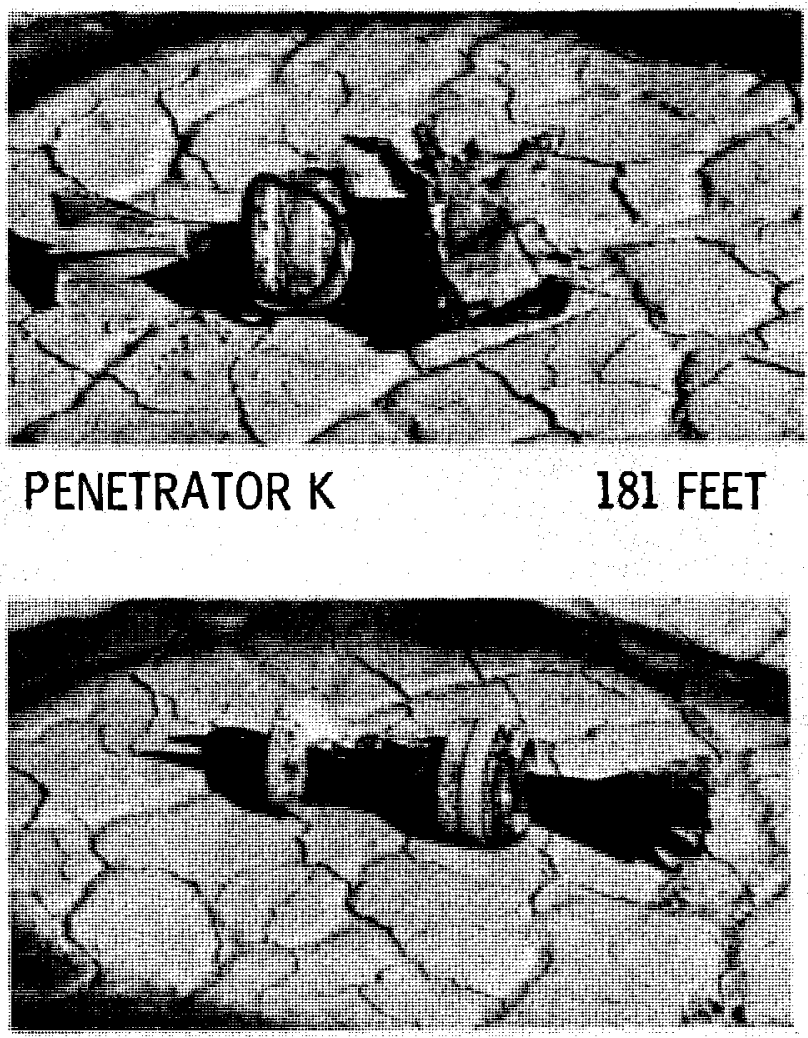

PENETRATOR L 
- Penetrator A. Penetrator A was found at ground zero $(0 \mathrm{ft})$ underneath the metal table with the sabot completely intact but with the tail fin completely melted away. Only the base of the fin remained. This penetrator was probably subjected to the greatest heat for the longest period of time. White powder was discovered at the base of the projectile. The powder appeared to be oxidized sealant.

- Penetrator B. Penetrator B was found at $30.5 \mathrm{ft}$ and was still part of a complete round which had not exploded. Part of the fiber container was attached to the round. Because the original orange paint on the sabot was still visible, it was concluded that the projectile had not been subjected to much heat.

- Penetrator $\mathrm{C}$. This penetrator was found at $46 \mathrm{ft}$ and was part of a complete projectile which was partially enclosed in a fiber container. Only the tail fin of the projectile was exposed. It appears that the container had been slightly charred.

- Penetrator D. Penetrator D was found at $73 \mathrm{ft}$ and was still part of the complete projectile. This projectile was partially encased in the fiber canister and did not appear to be charred.

- Penetrator E. This penetrator was found at $83 \mathrm{ft}$ and was still part of the complete projectile. The projectile was not charred and the orange paint on the sabot could still be seen. Part of a fiber container enclosed the projectile. The windshield was slightly bent, probably due to impact with the ground.

- Penetrator F. Penetrator F was found at $90 \mathrm{ft}$ and was definitely subjected to fire as seen from the discoloration of the rear of the sabot and tail fin. Except for a melted or missing plastic compression ring, the projectile was complete.

- Penetrator G. This penetrator was found at $97 \mathrm{ft}$ and was part of a complete projectile. The projectile was only slightiy burned as shown by the discoloration of the sabot and section of fiber container surrounding the projectile. No other damage was noted. 
- Penetrator H. Penetrator $H$ was found at $100 \mathrm{ft}$ as part of a complete, undamaged projectile. The orange paint on the sabot was only slightly discolored due to heat.

- Penetrator I. Penetrator I was found at $117 \mathrm{ft}$ as a complete, projectile. The sabot was slightly discolored at the rear due to fire and was beginning to separate, possibly due to impact. The windshield was noticeably bent, again, likely due to impact with the ground.

- Penetrator J. This penetrator was found at $123 \mathrm{ft}$ and was definitely subjected to heat, as indicated by partial melting of the tail fin. The penetrator was still a part of the complete projectile and was encased in part of the fiber container. Partial melting of the plastic insert was noted. The white powder present at the rear of the sabot was assumed to be oxidized sealant.

- Penetrator K. Penetrator K was found at $181 \mathrm{ft}$ as a complete projectile. Part of the cartridge container was attached to the projectile. The paint on the sabot was slightly charred but the sabot was completely intact.

- Penetrator L. Penetrator $L$ was thrown the $\mathrm{farthest,} 347 \mathrm{ft}$, and was found as a complete projectile. The projectile was not burned nor was the penetrator damaged except for a slightly bent windshield.

Figure 8 shows three projectiles, each subjected to apparently varying degrees of degradation. The extremely black projectile (A) at the far right was found at ground zero; it is believed that this penetrator was subjected to the most severe burn conditions. Projectile L, at the far left of was found at $347 \mathrm{ft}$ and was most likely subjected to the least severe burn conditions but was thrown the farthest distance. The middle projectile (I) shown in Figure 8 was found at $117 \mathrm{ft}$ and suffered a damaged windshield, bent tail fin, and slightly separated sabot upon impact. The sabot of each was opened by cracking the compression ring to expose the complete penetrator. Although the penetrators were subjected to different conditions, the integrity of the depleted uranium appears to have been equally unaffected. Only the physical condition of the fins, windshields, and sabots were affected in this test, either by actual heat from the fire or by impact after being thrown from the fire. 


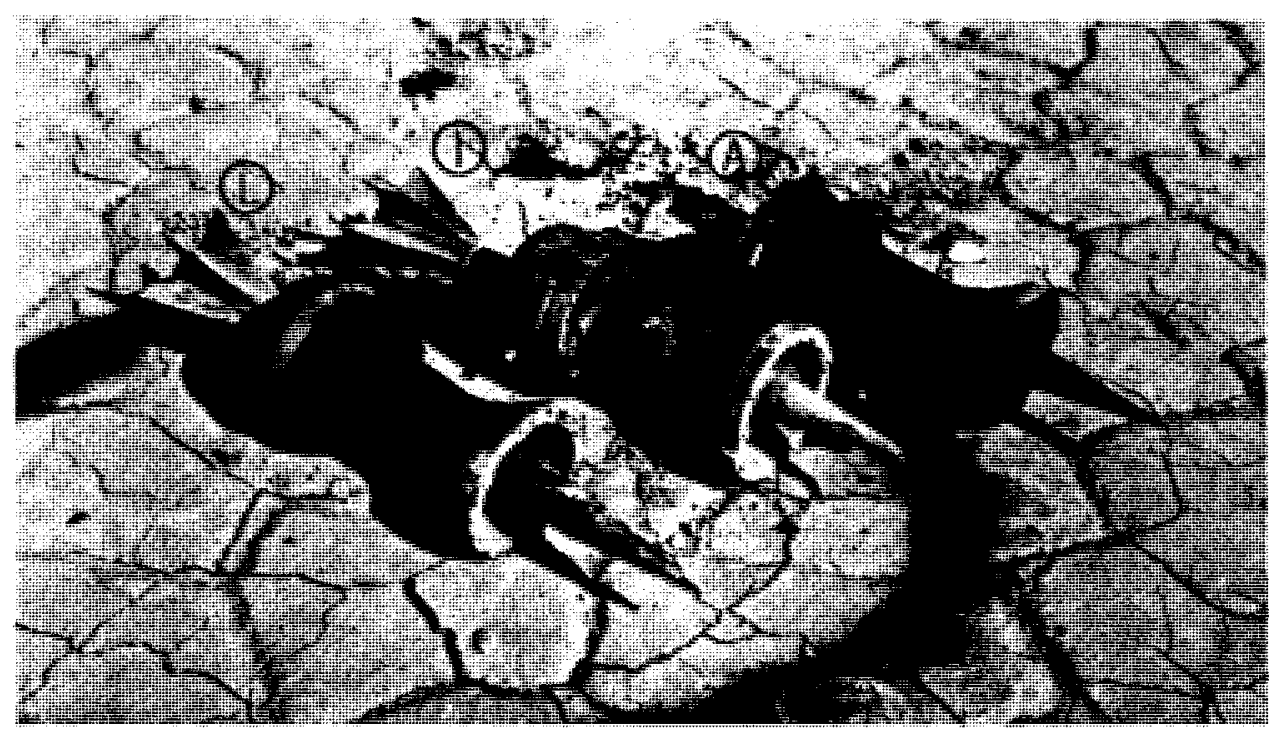

Sabots Intact

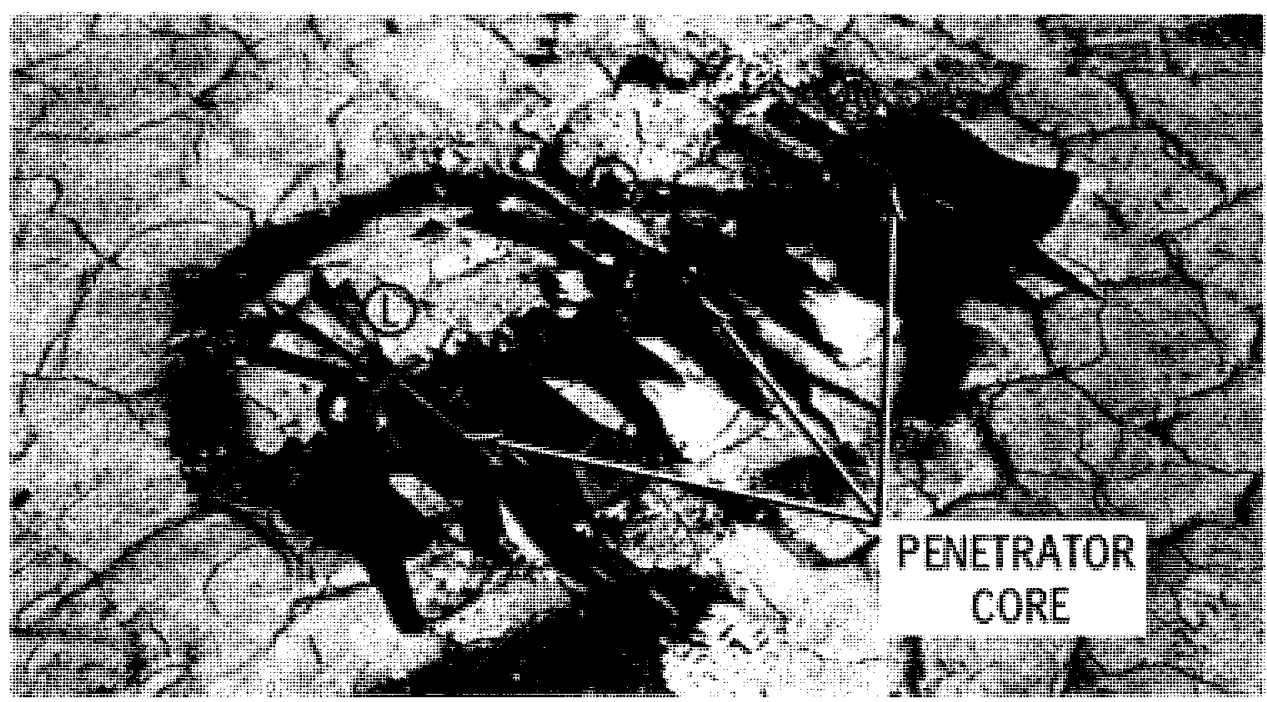

Sabots Laid Open

FIGURE 8. Comparison of Three Projectiles Subjected to the Burn Test 


\section{CONCLUSIONS}

The following conclusions about the atmospheric release of depleted uranium can be drawn from the external heat (burn) on October 17, 1977:

- The video tape, movie, still photos, and visual observation during the period of the burn show no yellow smoke characteristic of burning uranium. Absence of such smoke indicates that no significant release of uranium to the atmosphere occurred during the test.

- A11 twelve penetrators were found intact, complete, and with no apparent oxidation. Therefore, no depleted uranium was released to the atmosphere during the burn test.

Based on the above, it is concluded that there was no airborne radiological or toxicological hazard caused by burning twelve rounds of XM-774 ammunition in this test.

The above conclusions may not apply to the release of depleted uranium in other types of fires involving this ammunition because other factors may affect the fire. These factors include type of fuel, number of rounds, type of structure, etc.

A discussion of conditions that could cause possible oxidation and release of uranium is presented in the Appendix. 
APPENDIX:

OXIDATION AND IGNITION OF DEPLETED URANIUM 
,

.

. 


\section{APPENDIX}

\section{OXIDATION AND IGNITION OF DEPLETED URANIUM}

Twe lve rounds of $105 \mathrm{~mm}$ XM-774 antitank ammunition containing depleted uranium alloy penetrators were subjected to a burn test at Frenchman Flat at the Nevada Test Site on October 18, 1977. Ten of the 12 projectiles were recovered following the test as complete projectiles (sabots, penetrators tail fins and windshields intact and complete). As shown in Figure 7 of this report, two projectiles, designated $A$ and $J$, exhibited some degree of burn damage, but there was no indication of unusual oxidation or ignition of either penetrator. Melting of a single fin in the aluminum tail assembly was observed in projectile $\mathrm{J}$ (Figure 7), which was recovered $123 \mathrm{ft}$ from ground zero. No charring of the plastic compression ring or melting of the aluminum windshield was noted. A second unit ( $A$ in Figure 7 ), recovered at ground zero under the test stand, exhibited charring of the plastic compression ring and complete loss of the aluminum tail assembly. The aluminum windshield remained intact, however.

Some listed melting points of aluminum and aluminum alloys range from $480^{\circ}$ to $650^{\circ} \mathrm{C}$ (3) It appears that portions of the two penetrators of units $A$ and $J$ were subjected to temperatures in this range during some period of the test. Following the test, the compression rings were removed from the sabot of $A$ and two other units that showed little external fire damage, $I$ and $L$. Appearances of all three penetrators were similar (Figure 8), indicating the conditions imposed by the burn test did not result in observable additional oxidation.

The oxidation of uranium in air is by diffusion of oxygen ions through the oxide film. (4) The reaction is exothermic. (4) The rate can be controlled by the kinetics of the reaction or the diffusion of oxygen, depending on the characteristics of the oxide film and temperature. Oxidation rates for various temperature regimes have been reported. $(6,7,8)$ Baker and Bingle ${ }^{(8)}$ present three equations for the oxidation of $\beta$-quenched uranium: 


$$
\begin{array}{ll}
300<T<450 & W^{0.8}=1.0 \times 10^{5} \mathrm{t}[\exp -(16,800 / \mathrm{RT})] \\
T=450 & W=0.840 \mathrm{t} \\
T=>450 & W^{1.2}=1.8 \times 10^{4} \mathrm{t}[\exp -(14,300 / R T)]
\end{array}
$$

where

$$
\begin{aligned}
& T=\text { temperature, }{ }^{O} \mathrm{C} \\
& W=\text { quantity of oxygen consumed, } \mathrm{mg} / \mathrm{cm}^{2} \\
& t=\text { time, minutes } \\
& R=\text { universal gas constant }
\end{aligned}
$$

The reaction accelerates slightly between $300^{\circ}$ and $450^{\circ} \mathrm{C}$ and decelerates slightly above $450^{\circ} \mathrm{C} .{ }^{(9)}$ "Alloying additions have a profound effect on the oxidation and ignition of uranium." $(9)$ The presence of a few atom percent of titanium results in an increased reaction rate around $500^{\circ}$ C. ${ }^{(9)}$

It has been suggested that the ignition of uranium metal results simply from the accumulation of heat generated by oxidation. (9) Ignition is defined as when "the slope of the temperature-time curve of a self-heating specimen becomes nearly vertical and substantial increase in temperature occurs." $(4)$ The ignition temperature often is determined experimentally by the "intersection point between linear extensions of the pre-ignition heating rate and the post-ignition self-heating rate taken from the temperature-time record." $(9)$ The temperature is that of the metal mass and depends upon a balance of heat loss and gain. Figure A-l plots the calculated heat loss or generation rate of uranium versus temperature. The external temperature at which ignition occurs depends upon a variety of factors.

Ignition temperatures vary with specific area--the smaller the surface-to-mass ratio, the higher the ignition temperature. Figure A-2 shows this relationship for uranium. The DU penetrators are cylinders approximately $2.5 \mathrm{~cm}$ in diameter by $35 \mathrm{~cm}$ long, with a mass of $3.3 \mathrm{~kg}$. Threads are machined into the surface for attaching the sabot and tail assembly. The surface-to-mass ratio is estimated to be in the 0.1 to 0.2 $\mathrm{cm}^{2} / \mathrm{g}$ range, which is lower than any values plotted in Figure $\mathrm{A}-2$. This indicates an ignition temperature in excess of $700^{\circ} \mathrm{C}$. The presence of an alloying material such as titanium could reduce the ignition temperature. 


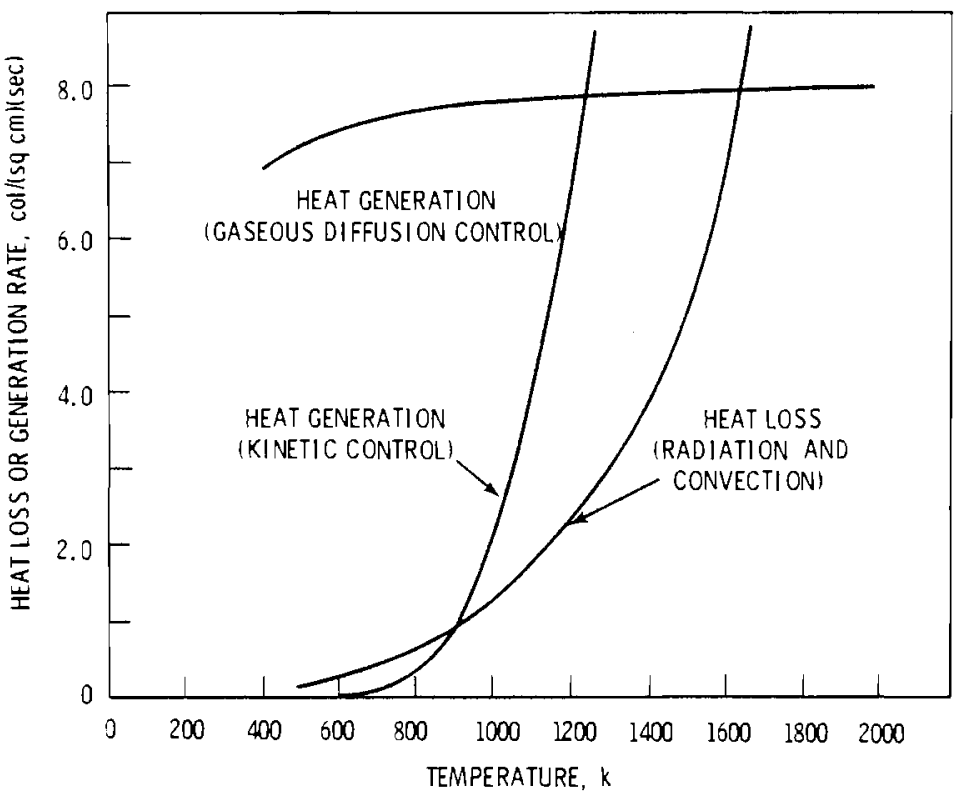

FIGURE A-1. Effect of Temperature on Heat
Loss or Heat Generation Rates (5)

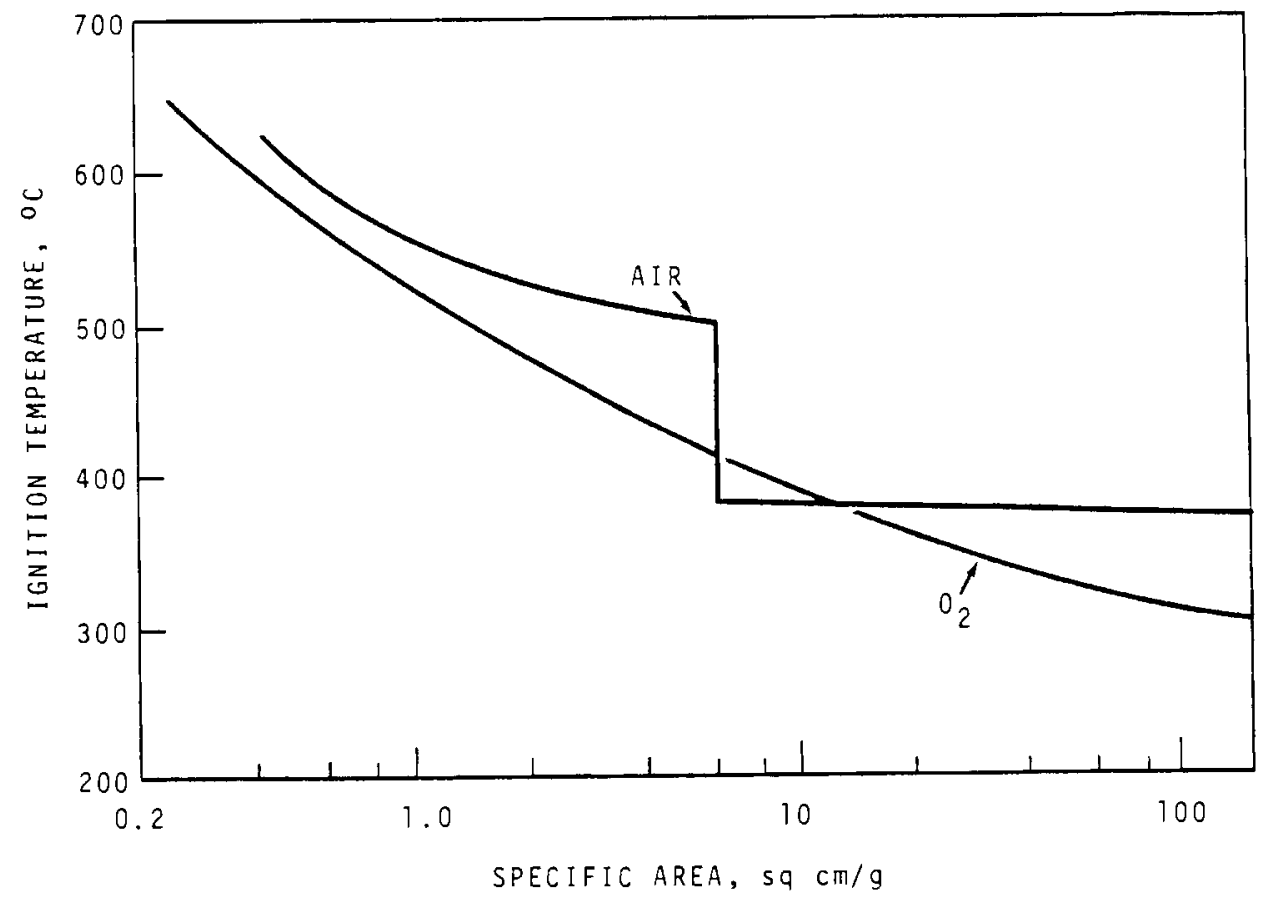

FIGURE A-2. Dependence of Uranium Ignition on Specific Area(8) 
The appearance of the projectiles following the burn test indicates that test conditions may not have been sufficiently rigorous to assess the potential for airborne release of uranium from penetrators when subjected to high temperatures. In the burn test, banded boxes of munitions were burned in the open. The vigorous reaction of the most heat-sensitive element, the propellant, hurled 11 of 12 projectiles out of the fire. The fire burned for only about one-half hour, but that was long enough to cause the rounds to explode.

It appears that a fire within an enclosure, such as a warehouse, railway car, ship, etc., could impose more severe conditions than those in the burn test. The enclosure could prevent the projectiles from escaping the fire zone and could be sufficiently rigid to cause fragmentation of the penetrators, thereby increasing the surface-to-mass ratio. The penetrators, then, might be subjected to conditions that could lead to ignition. Once ignited, oxidation of uranium in air could lead to metal temperatures around $1400^{\circ} \mathrm{c}^{(8)}$ and could be a strong ignition source. Some consideration should be given to methods of extinguishing fires involving burning penetrators. Figure $A-3^{(8)}$ shows that all the oxide would ultimately be $\mathrm{U}_{3} \mathrm{O}_{8}$ if heated to $>200^{\circ} \mathrm{C}$ in air. The size distribution of $\mathrm{U}_{3} \mathrm{O}_{8}$ particles produced by heating $\mathrm{UO}_{2}$ in air is shown in Figure $A-4$. The size distribution tends to be more coarse at temperatures above $800^{\circ} \mathrm{C}$.

It is recommended that experiments with full sized penetrators be conducted to determine if they can be ignited in air (or oxygen-depleted air) at temperatures to $\sim 1200^{\circ} \mathrm{C}$, the flame temperature of petroleum fires, with natural convection. If the penetrators can be ignited, the following questions need to be answered: what is the probability of such an occurrence, and what are the characteristics of the aerosol fraction and residue, such as size distribution, and solubility of oxides in body fluids?

This information would provide a more reliable estimation of the potential radiological downwind consequences of DU projectile involved in fires. 


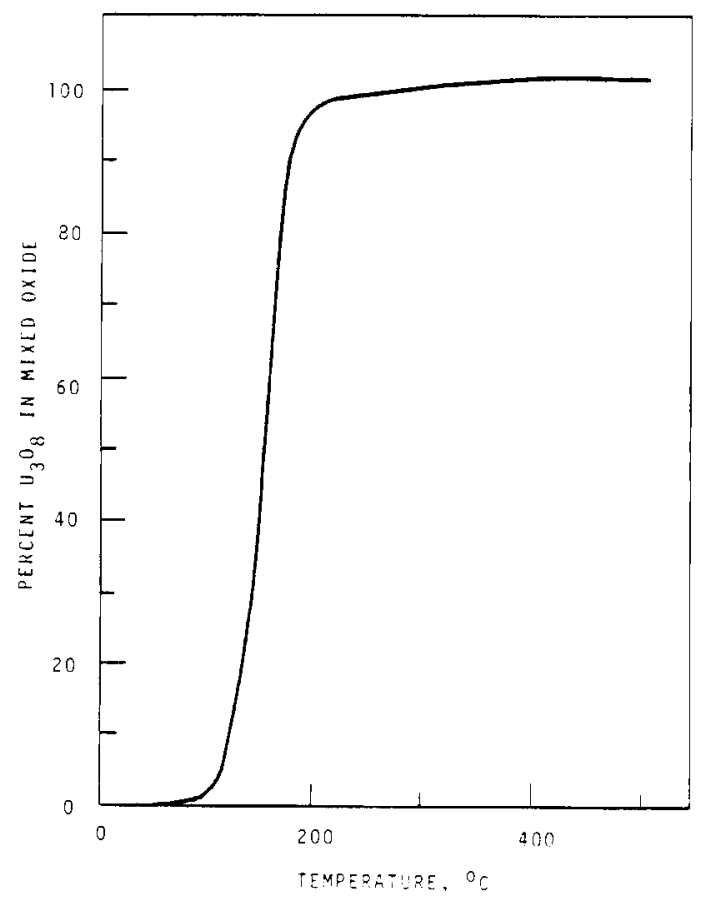

FIGURE $A-3$. Percentage of $\mathrm{U}_{3} \mathrm{O}_{8}$ Formed by Oxidizing Uranium in Air (8)

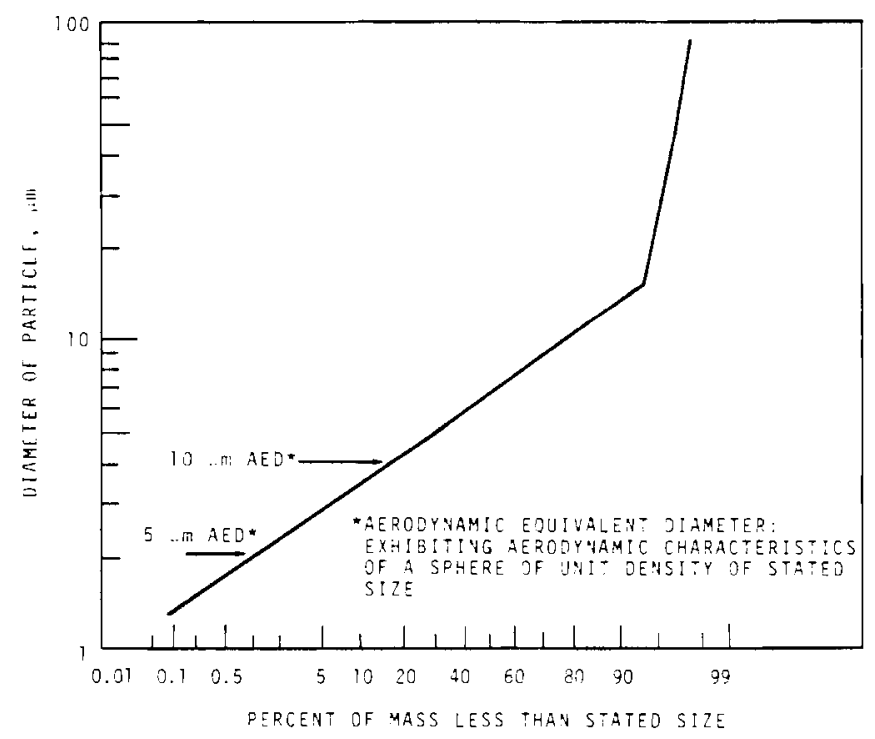

FIGURE A-4. Size Distribution of $\mathrm{U}_{3} \mathrm{O}_{8}$ Powder by the Air Oxidation of a Sintered $\mathrm{UO}_{2}$ Pellet at $500^{\circ} \mathrm{C}$ for One Hour (10) 
. 


\section{REFERENCES}

1. G. J. Gray. XM-774 Hazard Classification Test of the Cartridge, $105 \mathrm{~mm}$, APFSDS-T, Large Caliber Weapons Systems Laboratory, U. S. Army Armament Research and Development Command, Dover, NJ (in preparation).

2. Explosive Hazard Classification Procedure, TB 700-2, BUWEPSINST 8020.3, to 11A-1-47, OSAR 8220.7, Department of the Army, the Navy, and the Air Force, and Defense Supp ly Agency, Washington, DC, May 1967.

3. R. B. Norden, "Materials of Construction." Section 23 in The Chemical Engineer's Handbook, 5th Edition, R. H. Perry and C. H. Chitton, Ed., McGraw-Hi17 Book Co., New York, NY, pp. 23-47, 1973.

4. W. D. Wilkinson, Uranium Metallurgy. Interscience Publishers, New York, NY, 1962.

5. L. Leibouitz, L. Baker, Jr., J. G. Schnizlein, L. W. Mishler, and J. D. Bingle, "Burning Velocities of Uranium and Zirconium in Air." Nuclear Science and Engineering 15 (23:395-403), 1965.

6. R. K. Hilliard, Oxidation of Uranium in Air at High Temperatures. HW-58022, General Electric Company, Hanford Atomic Production Operations, Richland, WA, 1958.

7. L. Leibouitz, J. G. Schnizlein, J. D. Bingle, and R. C. Vogel, "The Kinetics of Oxidation of Uranium between $125^{\circ}$ and 2500 C." Journal of The Electro-chemical Society 108 (12):1155-1159, 1961.

8. L. Baker Jr., and J. D. Bingle, "The Kinetics of Oxidation of Uranium between $3000^{\circ}$ and 6250 C." Journal of Nuclear Materials, 20:11-21, 1966.

9. L. Baker, ur. and R. C. Liimatainen, "Chemical Reaction." Ch. 17 in The Technology of Nuclear Reactor Safety, Vol 2, Reactor Materials and Engineering, T. J. Thompson and J. G. Becker ley, Eds., MIT Press, Cambridge, MA, 1964.

10. M. Iwasaki, T. Sakurai, N. Ishikawa, and Y. Kobayashi. Oxidative Pulverization of $\mathrm{UO}_{2}$ Pellets, JAERI-1174, Japan Atomic Energy Research Institute, March 1969. 


\section{DISTRIBUTION LIST}

No. of

Copies

OFFSITE

A. A. Churm

DOE Chicago Patent Group

9800 South Cass Avenue

Argonne, IL 60439

2 Commander

Defense Documentation Center

ATTN: DDC-TA

Cameron Station

Alexandria, VA 22314

Office of Secretary of Defense

(Health Affairs)

ATTN: Lt. Col. B. Chase,

Pentagon, Room E171

Washington, DC 20301

Office of Secretary of Defense

Office of Director of Defense

Research and Engineering

ATTN: Mr. J. Persh

Washington, DC 20301

Secretary of the Army for

Research, and Development and Acquisition

ATTN: Col. J. Amee 1

Pentagon, Washington, DC 20301

2 Office of Assistant Secretary of Defense for Atomic Energy

ATTN: Maj. P. Oppenheim, Pentagon, Room 3-E-1069 Washington, DC 20301

Honorable Percy A. Pierre

Assistant Secretary of the Army for Research, Development and Acquisition

Department of the Army

Washington, DC 20310
No. of

Copies
Office of the Undersecretary of the Army

Deputy Undersecretary

(Operations Research)

ATTN: Mr. D. Hardison

Department of the Army

Washington, DC 20310

Undersecretary of Defense for Research \& Engineer ing ${ }^{\circ}$

Deputy Undersecretary

(Tactical Warfare Programs)

ATTN: BG F. J. Palermo

Department of Defense

Washington, DC 20310

Undersecretary of Defense for for Research \& Engineering Deputy Undersecretary

(Tactical Warfare Programs)

ATTN: Mr. C. McKinley

Department of Defense

Washington, DC 20310

Undersecretary of Defense for

Research \& Engineering

Deputy Undersecretary

(Tactical Warfare Programs)

ATTN: Mr. R. Moore

Department of Defense

Washington, DC 20310

Undersecretary of Defense for Research \& Engineering

Deputy Undersecretary (Rsch \&

Advanced Technology)

ATTN: Dr. R. Davis

Department of Defense

Washington, DC 20310 
Chairman

AMRAD Committee

ODDR\&E, Pentagon

ATTN: 3D-139, Col. G. Poole

Arlington, VA 20310

\section{Chairman}

AMRAD Committee

ODDR\&E, Pentagon

ATTN: 3D-139, Col. P. Lynch

Arlington, VA 20310

\section{Headquarters}

Department of the Army

ATTN: DACS-DMT,

BG D. Lawrence

Washington, DC 20310

Headquarters

Department of the Army

ATTN: DAMA-ARZ-A,

Dr. M. Lasser

Washington, DC 20310

Headquarters

Department of the Army

ATTN: DAMA-CSM-CA,

$\mathrm{Mr}$. E. Lippi

Washington, DC 20310

Headquarters

Department of the Army

ATTN: DAMA-CSM-CA,

LTC M. L. Townsend

Washington, DC 20310

Headquarters

Department of the Army

ATTN: DAMA-WSW, LTC Hinson

Washington, DC 20310

Headquarters

Department of the Army

ATTN: DAMA-WSZ-A, MG B. Lauer Washington, DC 20310
Project Manager

XM1 Tank System

ATTN: DRCPM-GCM,

BG (P) D. Babers

Warren, MI 48092

Project Manager

XMI Tank System

ATTN: DRCPM-GCM-SI,

Mr. D. Bartle

Warren, MI 48092

Project Manager for the M60 Tank

Michigan Army Missile Plant

ATTN: DRCPM-M60

Warren, MI 48090

Assistant Project Manager

XM1 Tank System

Tank Main Armament Development

ATTN: DRCPM-GCM-M,

LTC D. Appling

Dover, NM 07801

Assistant Project Manager

XM1 Tank System

Tank Main Armament Development

ATTN: DRCPM-GCM-M,

LTC J. Logan

Dover, NM 97801

Commander

US Army Aberdeen Proving Ground

ATTN: STEAP-PE-E, W. Russe 11

Aberdeen Proving

Ground, MD 21005

Director

US Army Ammunition Center

ATTN: SARAC-D, Mr. S. Jones

Savanna, IL 61074

Director

US Army Ammunition Center

ATTN: SARAC-D,

$\mathrm{Mr}$. K. Croscost

Savanna, IL 61074 
No. of

Copies

Commander

US Army Armament Rsch \& Dev Command

ATTN: DRDAR-CG, MG B. Lewis

Dover, NJ 07801

Commander

US Army Armament Rsch \& Dev Command

ATTN: DRDAR-TD, Dr. R. Weigle Dover, NJ 07801

Commander

US Army Armament Rsch \& Dev Command

ATTN: DRDAR-TDR, Dr. E. Eichelberger

Dover, NJ 07801

Commander

US Army Armament Rsch \& Dev Command

ATTN: DRDAR-SC, Dr. D. Gyorog

Dover, NJ 07801

Commander

US Army Armament Rsch \& Dev Command

ATTN: DRDAR-LC, Dr. J. Frasier

Dover, NJ 07801

Commander

US Army Armament Rsch \& Dev Command

ATTN: DRDAR-SCM, $\mathrm{Mr}$. J. Corrie

Dover, NJ 07801

Commander

US Army Armament Rsch \& Dev Command

ATTN: DRDAR-LCU-D-T,

$\mathrm{Mr}$. R. Davitt

Dover, NJ 07801
No. of

Copies

Commander

US Army Armament Material

Readiness Command

ATTN: DRSAR-CG,

MG W. E. Eicher

Rock Island, IL 61201

Commander

US Army Armament Material

Readiness Command

ATTN: DRSAR-LEA,

Mr. E. Beckman

Rock Island, IL 62101

Commander

US Army Armor Center and School

ATTN: MG T. V. Lynch

Fort Knox, KY 40121

Commander

US Army Armor Center and School

ATTN: Mr. M. Falkovitch

Fort Knox, KY 40121

6 Commander

US Army Armament Rsch \& Dev Command

ATTN: DRDAR-SCM,

Dr. E. W. Bloore

Dover, NJ 07801

Director

US Army Ballistic Research Laboratory

ATTN: DRDAR-B 1t,

Mr. R. Vitali

Aberdeen Proving

Ground, MD 21005

Director

US Army Ballistic Research Laboratory

ATTN: DRDAR-BLT, Dr. W. Gillich

Aberdeen Proving Ground, MD 21005 
No. of

Copies

Director

US Army Ballistic Research

Laboratory

ATTN: DRDAR-AD-SA,

Mr. R. Mark 1 and

Aberdeen Proving

Ground, MD 21005

Commander

US Army Combined Arms Combat Development Activity

ATTN: APCA-BC,

MG L. C. Menetrey

Fort Leavenworth, KA 66027

Commander

US Army Environmental Hygiene Agency

ATTN: HSE-O, LTC J. Thiessen

Aberdeen Proving Ground, EA, MD 21005

Director

US Army Human Engineering Laboratory

ATTN: DRXHE-HE, $\mathrm{Mr}$. Erickson

Aberdeen Proving Ground, MD 23801

Commander

US Army Logistics Center

ATTN: ATCL-MM, Mr. Thompson

Ft. Lee, VA 23801

Commander

US Army Logistics Evaluation Agency

ATTN: DALO-LEI, Mr. Frye

New Cumber land Army Depot

New Cumber land, PA 17070

Commander

US Army Material Development and Readiness Command

ATTN: DRCDMD, LTG R. J. Baer 5001 Eisenhower Avenue

Alexandria, VA 22333
No. of

Copies
Commander

US Army Material Development and Readiness Command

ATTN: DRCBSI, MG I. Hunt 5001 Eisenhower Avenue

Alexandria, VA 22333

Commander

US Army Material Development and Readiness Command

DRCDMA-ST, Mr. N. Kle in

5001 Eisenhower Avenue

Alexandria, VA 22333

Commander

US Army Material Development and Readiness Command

DRCSMA-ST, COL N. Vincent

5001 Eisenhower Avenue

Alexandria, VA 22333

Commander

US Army Material Development and Readiness Command

DRCSG, COL R. Cutting

5001 Eisenhower Avenue

Alexandria, VA 22333

Commander

US Army Material Development and Readiness Command

DRCPA-E, Mr. Pace

5001 Eisenhower Avenue

Alexandria, VA 22333

Commander

US Army Material Development and Readiness Command

DRCSF-P, Mr. D. Taras

5001 Eisenhower Avenue

Alexandria, VA 22333

Director

US Army Materials \& Mechanics Research Center

ATTN: DRXMR-X, Or. E. Wright Watertown, MA. 02172 
Director

US Army Materials \& Mechanics Research Center

ATTN: DRXMR-AR, Mr. S. Levin Watertown, MA. 02172

Director

US Army Materials Systems Analys is Activity

ATTN: DRXSY, Dr. J. Sperrazza Aberdeen Proving Ground, MD 21005

Director

US Army Materials Systems Analys is Activity

ATTN: DRXSY-GA, Mr. W. Brooks Aberdeen Proving

Ground, MD 21005

Director

US Army Material Systems

Analys is Activity

ATTN: DRXSY-GA, Mr. J. McCarthy

Aberdeen Proving

Ground, MD 21005

Commander

US Army Missile Command

ATTN: DRCPM-LCE,

Mr. B. Crosswhite

Redstone Arsena], AL 35809

Commander

US Army Mobility Equipment

Research and Development

Command

ATTN: DRSME-RZT,

Tech Doc Cntr, 81dg. 315

Fort Belvoir, VA 22060

Commander

US Army Research Office

ATTN: Dr. G. Mayer

P. 0. Box 12211

Research Triangle Park, NC 27709
Commander

US Army Research Office

ATTN: Dr. E. Saibel

P. O. Box 12211

Research Triangle Park, NC 27709

Commander

US Army Tank Automotive Research and Development Command

ATTN: DRDTA-RWL

Warren, MI 48090

Commander

US Army Tank Automotive Research and Development Command

ATTN: DRDTA-RKA,

Mr. V. Pagano

Warren, MI 48090

Commander

US Army Test \& Evaluation Command

ATTN: DRSTE-DCG, BG P. Bolte Aberdeen Proving

Ground, MD 21005

Commander

US Army Test \& Evaluation Command

ATTN: DRSTE-AR, Mr. Brown Aberdeen Proving Ground, MD 21005

Commander

US Army Test \& Evaluation Command

ATTN: DRSTE-CE

Aberdeen Proving

Ground, MD 21005

Commander

US Army Test \& Evaluation Command

ATTN: DRSTE-PP-E

Aberdeen Proving Ground, MD 21005 
No. of

Copies

Commander

US Army Test \& Evaluation Command

ATTN: DRSTE-ST, Mr. John Starkey

Aberdeen Proving Ground, MD 21005

Commander

US Army Training and Doctrine Command

ATTN: GEN. D. A. Starry

Fort Monroe, Hampton, VA

23651

Director

US Army TRADOC Systems Analys is Activity

ATTN: ATAA-SA

White Sands Missile

Range, NM 88002

Commander

Naval Facilities Engineering Command

Code 04N2, Mr. G. Hendrix

200 Stoval1 Street

Alexandria, VA 22332

Commander

US Naval Ordinance Systems Command

ATTN: ORD-9132

Washington, DC 20360

Superintendent

US Naval Postgraduate School

ATTN: Dir of Lib

Monterey, CA 93940

Commander

Naval Sea Systems Command

ATTN: PMS-404-31, Mr. D. Ayer Washington, DC 20362

Commander

US Naval Surface Weapons Center

ATTN: Code WR-32, S. Fishman

White Oak, MD 20910
No. of

Copies

Commander

US Naval Surface Weapons Center

ATTN: Code DG-52, W. Wishad

White Oak, MD 20910

Commander.

US Marine Corps Ln Office

Aberdeen Proving

Ground, MD 21005

Commander

US Air Force Headquarters

ATTN: SG-PA, LTC J. Bayer

Washington, DC 20314

HQ ADTC/CSV

ATTN: Maj. R. Conrad

Eglin AFB, FL 32542

HQ ADTC/DLV

ATTN: Dr. J. Cornette

Eglin AFB, FL 32542

Commander

US Air Force Tactical Air Command

ATTN: SG-PA, LTC J. Coughlin

Langley AFB, VA 23665

Los Alamos Scientific Laboratory

ATTN: Dr. W. Hanson

Environmental Studies Group $\mathrm{H}-8$

Mai1 Stop 490

Los Alamos, NM 87545

National Lead Company of Ohio

ATTN: Mr. L. Levy

Box 39158

Cincinnati, OH 45239

Rockwe 11 International

Rocky Flats Plant

ATTN: Dr. M. Werkema,

B1dg. 123, P. 0. Box 464

Golden, CO 80401 
No. of

Copies
No. of

Copies

Union Carbide Corporation

Nuclear Division

ATTN: Mr. M. Sanders

P. 0. Box $Y$

Oak Ridge, TN 37830

Nuclear Regulatory Commission

Division of Fuel Cycle and

Material Safety

ATTN: Mr. E. Wright

Washington, DC 20555

Genera 1 Electric Company

ATTN: R. Schell

Burlington, VT 05401

University of California

Los Alamos Scientific Laboratory

ATTN: D. Sandstrom, CMB-6

Los Alamos, NM 87544

Air Force Materiel Laboratory

ATTN: LTM, S. Inouye

Wright-Patterson AFB, OH 45433

Air Force Materiel Laboratory

ATTN: YXD, Cpt. D. Schuur

Wright-Patterson AFB, OH 45433

$\mathrm{HQ}, \mathrm{ADTC}$

ATTN: CEEDO/CC Detachment 1

Tynda 11 AFB, Fl 32403

USA Ordnance Center and School

Aberdeen Proving

Ground, MD 21005

Commander

USA Armament Materie 1

Readiness Command

ATTN: DRSAR-ASR, LTC Counihan

Rock Is land, IL 61201

Commander

USA Armament Materiel

Readiness Command

ATTN: DRSAR-MAD-C, Mr. P. Shaw

Dover NJ 07801
Commander

USA Materiel Development and Readiness Command

ATTN: DRCIRD, $\mathrm{Mr}$. B. Dunetz

Alexandria, VA 22333

Commander

USA Materiel Development and Readiness Command

ATTN: DRCDE-DW, Mr. W. Hunt

Alexandria, VA 22333

Commander

US Army DESCOM

ATTN: DRSDS-CG

Letterkenny Army Depot

Chambersburg, PA

Project Manager

Munitions Production Base

Modernization and Expansion

ATTN: DRCPM-PBM, Mr. C. Kol is

Dover, NJ 07801

Project Manager, DIVADS

ATTN: DRCPM-DIVADS

Dover, NJ .07801

Commander

US Army Armor Center

ATTN: ATZK-CD-MS, LTC Walters

Ft. Knox, KY

Commander

Air Force Systems Command

ATTN: SDZW, Maj. Buchta

Andrews AFB, Washington, DC 20334

27 DOE Technical Information Center 
No. of

Copies

ONSITE

DOE Richland Operations Office

R. E. Ransom

25 Battelle-Northwest

W. T. Bartlett

J. S. Burlison

R. L. Gilchrist (10)

J. A. Glissmeyer

J. Mish ima

G. B. Parker (3)

L. C. Schwend iman

J. M. Selby

Technical Information Files (5)

Technical Publications 